\title{
Diagnostic problems in a patient with pulmonary fibrosis and soft tissue calcifications: scleromyositis
}

\author{
Trudności diagnostyczne u pacjentki z włóknieniem płuc i zwapnieniami w tkankach \\ miękkich: scleromyositis
}

\author{
Ewa Walewska, Robert Rupiński \\ Clinic and Polyclinic of Rheumatology, Institute of Rheumatology, Warsaw \\ Klinika i Poliklinika Reumatologii, Instytut Reumatologii im. prof. dr hab. med. Eleonory Reicher w Warszawie
}

Key words: secondary hyperparathyroidism, scleromyositis, systemic sclerosis without scleroderma, soft tissue calcifications.

Słowa kluczowe: wtórna nadczynność przytarczyc, twardzina z zajęciem mięśni, twardzina bez zajęcia skóry, zwapnienia w tkankach miękkich.

\begin{abstract}
Summary
Overlap syndromes are a spectrum of disorders with mixed clinical features of different connective tissue diseases, which often make the diagnostic process difficult. The article describes the case of a $57-$ year-old woman with arthralgia, interstitial lung disease and soft tissue calcifications. Despite the absence of any typical skin lesions, predominant clinical features of pulmonary fibrosis and vascular changes in the nailfold capillaroscopy were strongly suggestive of scleroderma-like syndrome. During the course of the disease, six months later, laboratory tests revealed elevated creatine phosphokinase and electromyography confirmed features of primary muscle damage. Since muscle involvement and soft tissue calcifications might be characteristic for scleromyositis, a cutaneous-muscular biopsy was performed to confirm the diagnosis. We speculate that early development of calcifications in this case could be accelerated by vitamin $\mathrm{D}$ deficiency and secondary hyperparathyroidism. Small doses of glucocorticosteroids, azathioprine and supplementation of vitamin D were sufficient to control clinical symptoms of the disease.
\end{abstract}

\section{Introduction}

The case report presented here highlights the difficulties with diagnosis of a patient with arthralgia, pulmonary fibro-

\section{Streszczenie}

Choroby tkanki łącznej, a zwłaszcza zespoły nakładania, ze względu na znaczną różnorodność i zmienność objawów klinicznych mogą być powodem trudności diagnostycznych. W pracy przedstawiono przypadek 57-letniej kobiety z włóknieniem płuc, dolegliwościami bólowymi stawów rąk oraz zwapnieniami w tkankach miękkich. Włóknienie płuc oraz obecność zmian naczyniowych w badaniu kapilaroskopowym, przy braku typowych skórnych cech twardziny układowej, sugerowały rozpoznanie zespołu twardzinopodobnego. Pół roku od pierwszej hospitalizacji u chorej stwierdzono podwyższenie aktywności kinazy kreatynowej w surowicy, z towarzyszącymi objawami uszkodzenia pierwotnie mięśniowego w badaniu elektromiograficznym. Zajęcie układu mięśniowego uznano za objaw zespołu określanego jako scleromyositis, w którym często występują zwapnienia w tkankach miękkich. Rozpoznanie potwierdzono badaniem histopatologicznym wycinka skórno-mięśniowego. Wczesne wystąpienie zwapnień mogło być spowodowane niedoborem witaminy D i wtórną nadczynnością przytarczyc. W leczeniu chorej zastosowano z powodzeniem małe dawki glikokortykosteroidów, azatioprynę i suplementację witaminą $\mathrm{D}$.

sis and soft tissue calcifications without any disease-specific autoantibodies.

Despite the fact that the patient had no clinical features of skin involvement, the diagnosis of scleromyositis was finally established.

Address for correspondence:

lek. Ewa Walewska, Klinika i Poliklinika Reumatologii, Instytut Reumatologii, ul. Spartańska 1, 02-637 Warszawa, tel. +48 22844 42 41, w. 214, faks +48 2284487 57, e-mail: ewalewska@interia.pl

Submitted: 4.10 .2012 


\section{Case presentation}

The 57-year-old Caucasian woman with suspicion of rheumatoid arthritis complicated by pulmonary fibrosis was admitted to the Institute of Rheumatology in Warsaw. The patient complained of pain in the hands and feet with periodic oedema of the fingers. The first symptoms appeared about six years ago. Ambulatory diagnosis of rheumatoid arthritis was initially established and the patient received treatment with glucocorticosteroids and methotrexate, which was withdrawn after a few months because of pulmonary fibrosis. Comorbidities included type 2 diabetes mellitus and arterial hypertension. On admission the patient reported only tenderness of hands and knee joints. Physical examination revealed subcutaneous, hard, painless nodules (3-6 $\mathrm{mm}$ in diameter) located in soft tissues in the area of the left wrist and fingers. Apart from an elevated level of $\alpha 2$-globulins there were no clinically significant abnormalities in laboratory tests. The autoantibody profile was negative (anti-nuclear antibodies - ANA, anti-citrullinated protein antibodies - ACPAs, rheumatoid factor - RF).

$X$-rays of hands and feet showed generalized osteoporosis and a few calcifications of different size in soft tissues in the area of distal and proximal interphalangeal joints with a left side predominance. A cluster of granular calcifications was present in the area of the distal base of the left ulna and features of osteoarthrosis were observed in DIP joints (Fig. 1). Chest $X$-ray revealed changes suggestive of pulmonary fibrosis.

The patient did not meet the classification criteria for rheumatoid arthritis. Firstly, on the radiologist's suggestion we considered sarcoidosis with pulmonary, skin and bone involvement. Detailed examinations that followed excluded sarcoidosis. Distribution and reticular pattern of changes in high-resolution computed tomography (HRCT)

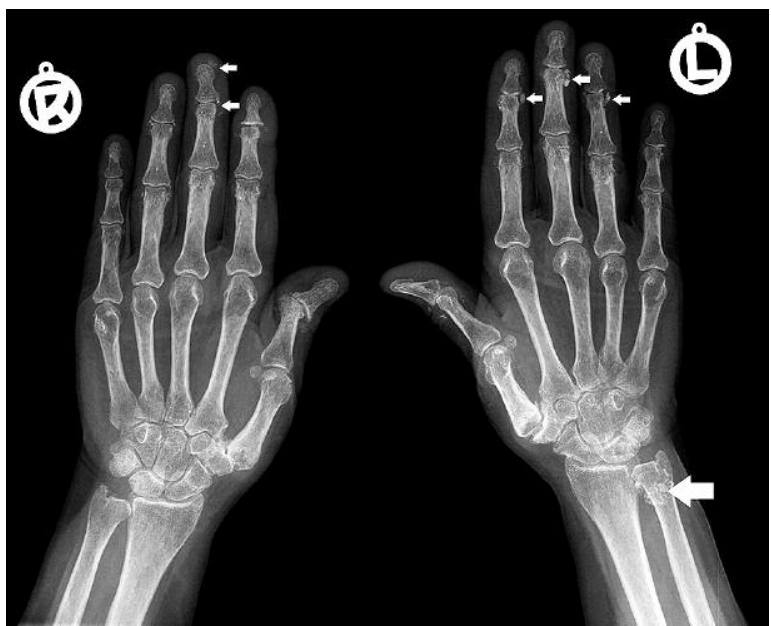

Fig. 1. Soft tissue calcifications in a patient with scleromyositis (X-ray of hands) was not characteristic for sarcoidosis and suggested pulmonary fibrosis in the course of the connective tissue disease. The patient was referred to a pulmonologist for pulmonary function tests.

Biopsy of a nodule from the left forearm revealed single inflammatory cells around superficial blood vessels of the skin (the histological picture was not typical for any specific disease).

Serum vitamin $25(\mathrm{OH}) \mathrm{D}_{3}$ level in this patient was $9.6 \mathrm{ng} /$ $\mathrm{ml}$ and indicated significant deficiency (normal range 30$80 \mathrm{ng} / \mathrm{ml}$ ). An elevated parathormone level of $140 \mathrm{pg} / \mathrm{ml}$ (normal range 15-88 pg/ml) with normal levels of serum calcium, inorganic phosphate, alkaline phosphatase, and albumin was found. The elevation of parathormone level together with vitamin D deficiency suggested secondary hyperparathyroidism; however, ultrasound examination of thyroid and parathyroid glands revealed no changes.

Despite the fact that the patient did not present Raynaud's phenomenon or any skin symptoms of scleroderma, we considered systemic sclerosis in the differential diagnosis. Nailfold capillaroscopy demonstrated nailbed oedema, some elongated capillaries with punctate haemorrhages, loss of capillaries and capillaries with fading loops. Microvascular abnormalities were characteristic for the active pattern of scleroderma, not for other connective tissue diseases. Barium x-rays of oesophagus demonstrated normal function. However, pulmonary fibrosis and vascular changes in this clinical setting suggested scleroderma-like syndrome.

Six months later laboratory tests revealed slightly elevated activity of creatine phosphokinase ( $458 \mathrm{U} /$; ; normal range 30-135 $\mathrm{U} / \mathrm{l})$, with normal muscle strength, but electromyography (EMG) confirmed primary muscle damage.

Additionally a cutaneous-muscular biopsy was performed to confirm the diagnosis. Histological examination revealed slight homogenization of collagen and scant lymphocyte infiltrations in the skin. Inflammatory infiltration with lymphocyte predominance, focal fibrosis in intramuscular tissue and slight muscle atrophy were found in the muscle tissue.

Then azathioprine treatment (1 mg/kg of body mass), prednisone ( $5 \mathrm{mg}$ per day) and vitamin D supplementation were implemented with positive effects on general condition and reduction of joint and bone pain.

\section{Discussion}

Soft tissue calcium deposits appear mostly in polymyositis or in overlap syndromes including scleroderma and myositis [1]. In the case presented in this report diagnosis of scleromyositis (the overlap syndrome of polymyositis and systemic sclerosis) without scleroderma was finally estab- 
lished. This form of overlap syndrome is rare as patients may have any of the characteristic features of internal organ involvement without having detectable skin features. Our patient did not present any form of skin thickening, digital pitting scars, or telangiectasia. The patient had calcifications, puffy fingers and finger joint contractures, which are detected significantly more often in patients with scleromyositis. In overlap syndromes cutaneous and muscle features of DM or PM are usually transient and may regress spontaneously, whereas those of scleroderma tend to persist. The studies by Marguerie et al. [2] and by Jabłońska et al. [3] demonstrated that the main clinical features of scleromyositis include transient Raynaud's phenomenon, scleroderma-like changes in the face and hands, arthralgia or arthritis, myositis or myalgia, and calcinosis (up to $46 \%$ of cases). Muscle involvement is usually mild, muscle enzymes are slight and usually not consistently elevated. Visceral involvement is often mild or absent. Pulmonary involvement presented as interstitial lung disease and fibrosis varies between $34 \%$ and $78 \%$ of cases. Sclerodermatomyositis differs from systemic sclerosis by the absence of hallmark cutaneous features such as indurations of the face and trunk or acro-osteolysis. It also differs from mixed connective tissue disease (MCTD) due to the lack of SLE symptoms and the absence of anti-RNP antibodies [4]. In patients with suspected systemic autoimmune disorders, a panel of disease-specific markers may help to establish the diagnosis and to assess the prognosis. Scleromyositis in the majority of cases is characterised by the presence of autoantibodies directed at components of the PM/SCL complex [5]. The absence of any autoantibodies in our patient, previously treated with steroids, does not exclude the diagnosis of scleromyositis.

Contradictory results have been reported regarding the correlation between clinical presentation and pathological muscular features; nevertheless, there is general agreement that histologically proven inflammatory myopathies have much better prognosis that non-inflammatory myopathies associated with systemic sclerosis [6]. Myositis usually regresses as a result of high-dose corticosteroid therapy, or even low-dose in a case of positive anti-PM/Scl antibodies. In contrast, non-inflammatory myopathies often result in milder clinical expression but do not respond to immunosuppressive treatment.

Because of soft tissue calcifications and elevated parathormone level, hyperparathyroidism was considered in our case. Secondary hyperparathyroidism appears to be a common pathway to compensate low calcium bioavailability in the case of vitamin $D$ deficiency, low calcium intake and oestrogen deficiency. In this patient the hydroxyvitamin D level was decreased, which might lead to vitamin D deficiency associated myopathy [7]. Experimental studies indicate that vitamin D metabolites direct- ly influence muscle cell maturation and function. An inadequate serum vitamin D status in humans is associated with muscle weakness, predominantly of the proximal muscle groups [8].

Soft tissue calcifications and radiological abnormalities in lungs could suggest sarcoidosis; however, the level of 25(OH)D in sarcoidosis is usually increased, as sarcoidal granuloma may produce vitamin $\mathrm{D}$, with subsequent hypercalcaemia and an elevated calcium-phosphate product.

Soft tissue calcifications may occur in the course of longstanding connective tissue diseases such as dermatomyositis, lupus erythematosus or systemic sclerosis. In juvenile dermatomyositis calcification occurs 3 times more frequently than in the adult-onset form and is diagnosed in almost $30-40 \%$ of patients $[9,10]$.

In the case presented here, the appearance of calcifications could be accelerated by secondary hyperparathyroidism caused by vitamin $D$ deficiency.

The clinical presentation of scleromyositis, a scleroderma/polymyositis overlap syndrome, may change during the course of the disease, and thus it could be the cause of difficulties in the diagnostic process.

The authors declare no conflict of interest.

\section{References}

1. Jablonska S, Blaszczyk M. Scleromyositis: a scleroderma/polymyositis overlap syndrome. Clin Rheumatol 1998; 17: 465-467.

2. Marguerie C, Bunn CC, Copier J, et al. The clinical and immunogenetic features of patients with autoantibodies to the nucleolar antigen PM/Scl. Medicine (Baltimore) 1992; 71: 327-336.

3. Jablonska S, Blaszczyk M. Scleroderma overlap syndromes. Adv Exp Med Biol 1999; 455: 85-92.

4. Amigues JM, Cantagrel A, Abbal M, Mazieres B. Comparative study of 4 diagnosis criteria sets for mixed connective tissue disease in patients with anti-RNP antibodies. J Rheumatol 1996; 23: 20552062.

5. Brouwer R, Vree Egberts WT, Hengstman GJ, et al. Autoantibodies directed to novel components of the PM/Scl complex, the human exosome. Arthritis Res 2002; 4: 134-138.

6. Ranque B, Bérezné A, Le-Guern V, et al. Myopathies related to systemic sclerosis: a case-control study of associated clinical and immunological features. Scand J Rheumatol 2010; 39: 498-505.

7. Allanore $Y$, Meune $C$, Kahan A. Systemic sclerosis and cardiac dysfunction: evolving concepts and diagnostic methodologies. Curr Opin Rheumatol 2008; 20: 697-702.

8. Smith R, Stern G. Muscular weakness in osteomalacia and hyperparathyroidism. J Neurol Sci 1969; 8: 511-520.

9. Janssen HC, Samson MM, Verhaar HJ. Vitamin D deficiency, muscle function, and falls in elderly people. Am J Clin Nutr 2002; 75: 611-615.

10. Pachman LM, Veis A, Stock S, et al. Composition of calcifications in children with juvenile dermatomyositis. Arthritis Rheum 2006; 54: 3345-3350. 